\title{
Modeling of motor fuel consumption in Serbia with projection to 2025
}

\author{
Dalibor Marinković ${ }^{1}$, Zoran Popović ${ }^{1}$, Aleksandar Orlović ${ }^{2}$, Mirjana Ristić ${ }^{2}$ \\ ${ }^{1}$ University of Belgrade, Institute for Chemistry, Technology and Metallurgy, Belgrade, Serbia \\ ${ }^{2}$ University of Belgrade, Faculty of Technology and Metallurgy, Belgrade, Serbia
}

\begin{abstract}
This study is based on the application of mathematical methods of statistical analysis that can be used to predict the development of motor fuel consumption in the Republic of Serbia. It is based on the linear dependence of consumption growth of motor fuel from the development of gross domestic product per capita, which is then corrected by introducing five additional influencing parameters. The model results indicate that the total consumption of motor fuels in Serbia from 2010 to 2025 will be increased by $26.5 \%$. Individual consumption of motor fuels shows different market tendencies. Diesel fuel consumption expects to continue intensive growth to 2025 , even though slightly slower than the achievements in the last decade. The current trend of declining demand for gasoline will be stopped from 2015-2016, then followed by slow growth of demand by 2025 . Consumption of liquefied petroleum gasses (LPG) will enter the phase of saturation in 2015.
\end{abstract}

Keywords: consumption of petroleum products; GDP; mathematical model; Republic of Serbia.

SCIENTIFIC PAPER

UDC 665.6/.7(497.11)“19“

Hem. Ind. 66 (3) 413-423 (2012)

doi: 10.2298/HEMIND110224105M

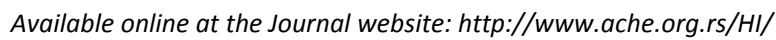

The prediction of energy consumption, and therefore motor fuel consumption, is an indispensable link in the process of creating long-term policies and strategies of maintaining the economic stability and development of any country. In this context, the modelling of motor fuel demand has been the subject of many studies [1-5]. Authors have mainly attempted to evaluate demand elasticities in relation to price and income [6-7]. Thus, the relationship between gross domestic product (GDP) and energy or oil product demand is well known $[2,4,8]$.

Current global energy consumption trends and concerns about global warming put mutually contradictory requirements. How does the expected intensive economic growth in middle income countries (Word Bank economies classification according to 2010 gross national income per capita, calculated using the World Bank Atlas method) [9] reconcile with the requirements for the rationalization of global energy consumptions? Economic growth inevitably leads to greater use of energy, and today the most common source of energy are fossil fuels. However, there are valid reasons to suggest that this contradiction could be resolved. First, in almost every case of increase in GDP, when a country evolves from a middle income to a high income country, fossil fuel consumption enters a stage of saturation [2]. Most of the countries where energy use growth is faster than the GDP are either low or middle

Correspondence: D. Marinković, Institute for Chemistry, Technology and Metallurgy, Njegoševa 12, 11000 Belgrade, Serbia.

E-mail: dalibor@ihtm.bg.ac.rs

Paper received: 24 February, 2011

Paper accepted: 7 December, 2011 income countries, while in high income countries, the GDP is grows faster than energy consumption [4]. Furthermore, the increasing price of fossil fuels encourages saving, and therefore the use of alternative fuels. Also, technological progress lead to production of more economical engines that will also help in rationalizing the consumption of fuel.

The importance of forecasting consumption of motor fuels can be observed by their current share of consumption in total energy consumption. Products obtained from fossil fuels are still the dominant global energy source -from the total world consumption of energy petroleum products account for $34.3 \%$ (of which about $84 \%$ is consumed in the form of motor fuels in the transport sector) [10]. In the past several years in Serbia, these products have participated in the final consumption of overall energy with about 39\%, excluding their use as a raw material in the petrochemical industry, etc. The current share of motor fuels (gasoline fuel, diesel fuel and liquefied petroleum gasses) in the national energy demand are at around $28 \%$, and the transport sector consumes about $89 \%$ of these products [11].

This study is based on the application of mathematical methods of statistical analysis that can be used to predict the development of motor fuel consumption in the Republic of Serbia. The designed model is based on the use of two parameters, which are generally easily available [7]. The first parameter is an economic indicator defined by GDP per capita. In order to makes this parameter even more realistic indicator of the level of standard of living in one country, it was introduced GDP $\mathrm{PPP}_{\mathrm{PC}}$, gross domestic product per capita calculated at purchasing power parity. GDP PPP ${ }_{\mathrm{PC}}$ is expressed in dol- 
lars, calculated at the time of writing this paper (current international USD) [12]. The second parameter is the amount of consumption of motor fuels. The linear correlation of these two parameters in the model is modified by introducing some correction factors. Their contribution in this model was evaluated according to their specific impact on consumption and some of them according to the specifics of the transport sector in Serbia.

Therefore, the development of motor fuel consumption for one country cannot be correlated exclusively and only with the growth of GDP. Factors affecting are the level of motorization (number of registered motor vehicles) and, average fleet mileage in passenger and freight traffic, degree of modernization and growth of the fleet, technological and technical progress which leads to reduction of specific consumption of motor fuels (energy efficiency of vehicles), the number of vehicles with air conditioning, development of the relations of consumption gasoline/diesel fuel, the level of substitution of fossil fuels to alternative fuels, industrial growth, the policy of state regulations, subvention in the energy sector, tax and price policy, etc. A particularly important factor is, of course, the level of price of motor fuels - when taking into account the longer term trends, instead short term variation that has smaller impact (as is the case recently when the price of crude oil in the two-year period, driven on from 60 to 150 USD and then to 35 USD and finally in the first quarter of 2011 to 100 USD per barrel).

\section{METHODOLOGY}

A mathematical model was developed using available statistics of the Republic of Serbia, neighbouring countries and European countries that have made transitions similar to that Serbia is now undergoing, as well as data published by the relevant institutions in the energy sector and scientific and review papers. This task was initially meant to be a selection and application of analytical techniques for the analysis of past trends in consumption of motor fuels and intensity of traffic in Serbia. Then, analyzing the existing motor fuel demand projections was performed for the countries or regions of similar size and level of development, with similar characteristics of supply and demand of petroleum products, in order to reach the relevant analogy. Going forward, the identification of factors affecting the consumption of motor fuels that can be quantified based on statistical data was approached. In the absence of an adequate database from the energy and transport sectors in Serbia, some of the qualitative impact factors on fuel consumption were quantified by an assessment of particular concern, as will be explained in the part of parameter identification in this paper.

Modelling of motor fuel consumption in Serbia is based on the correction of linear dependence of the volume of total consumption of motor fuels and the level of GDP PPP , identified in the period of 2001-2009. Justification for the assumption of the existence of linear correlation of GDP per capita and consumption of motor fuels, in addition to the conclusions of many authors $[2,6]$, can be found in time series analysis of relevant statistical data for Serbia. Figure 1 clearly illustrates the strong positive correlation of these two variables. Statistical analysis shows that the correlation coefficient between total consumption of motor fuels and GDP PPP $\mathrm{PC}$ is 0.94 .

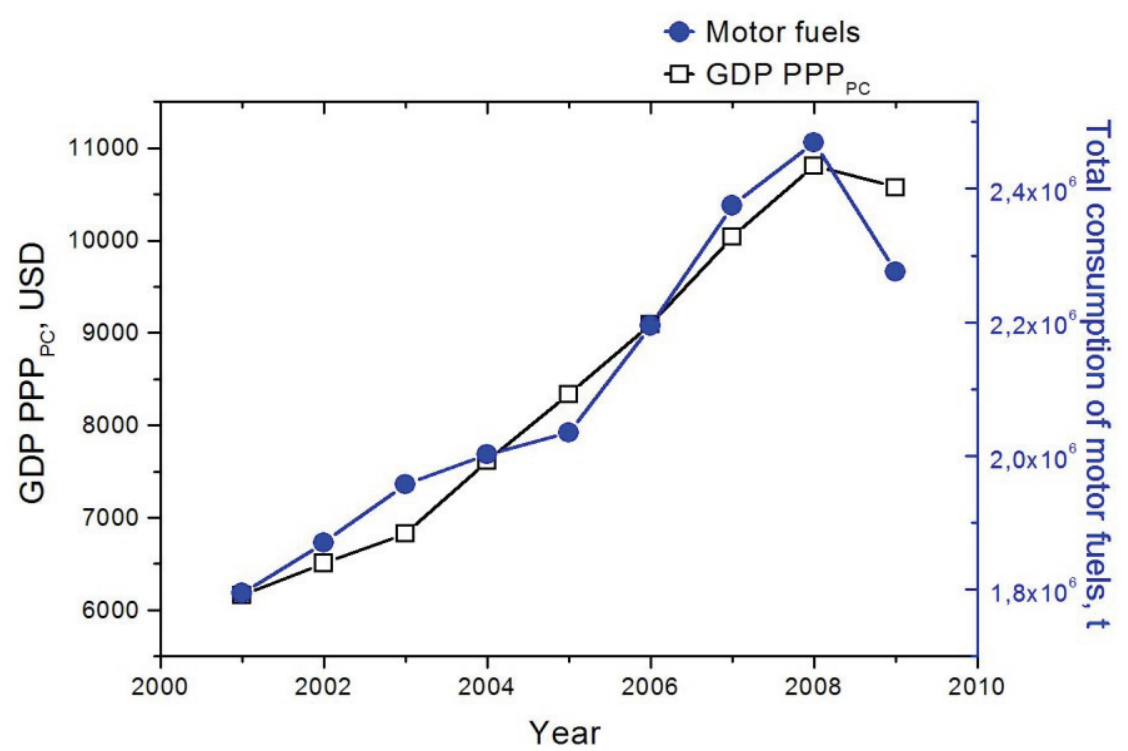

Figure 1. Correlation between gross domestic product per capita calculated at purchasing power parity (GDP PPP $P$ ) and total consumption of motor fuels in Serbia in the period 2001-2009. 
The motor fuels taken into consideration were gasoline, diesel and liquefied petroleum gas (LPG). Corrections were done using five parameters $\left(P_{1}\right.$ to $\left.P_{5}\right)$ :

$D_{\mathrm{uk}, j}=\left(a+b \times G D P P P P_{\mathrm{PC}, j}\right) \Sigma \mathrm{P}_{i, j}$

where $D_{\mathrm{uk}, j}$ represents the total consumption of motor fuels in the year $j ; a$ and $b$ are the intercept and slope of fitted linear dependence, respectively; $P_{i, j}$ are correction factors; $i$ is the number of correction factor, $1-5 ; j$ is the year, 2001-2025.

The historic volume of motor fuel consumption in Serbia was obtained from the Statistical Office of Serbia, the Serbian state energy balances and analytical documentation of the Refinery "NIS", while GDP PPP based on the use of data of the Statistical Office of Serbia and the International Monetary Fund (IMF).

Correction factors $P_{i}$ are the relevant parameters that affect on the consumption of motor fuels, derived from the analysis above mentioned influencing factors:

1) $P_{1}$ is the factor of specific fuel consumption;

2) $P_{2}$ is the average mileage factor;

3) $P_{3}$ is factor changes in crude oil price;

4) $P_{4}$ is the alternative fuels impact factor;

5) $P_{5}$ is the impact factor of vehicles air conditioning.

It should be noted that for any of the analyzed influential factors there are almost no relevant data regarding the Republic of Serbia. This has prompted several different concepts to be applied, separately or in combination: carrying out of analogies, comparative analysis, and the analysis of statistical data of other countries. Each parameter had an independent analysis according to their different nature, and therefore some are simple and others are more complex.

\section{Parameter identification}

Gross domestic product per capita calculated at purchasing power parity (GDP PPP $P_{P C}$

As noted above, the GDP calculated by purchasing power parity by 2010 was taken from the Statistical Office of Serbia. For the period until 2016,the GDP were taken as forecasts of the IMF [13]. For the period after 2016, there are no projections of relevant international organizations dealing with macro-economic forecasts. Based on analogies with neighbouring countries that have made the transition and the latest projections presented in the recently launched strategy paper "Post-Crisis model of economic growth and development of Serbia 2001-2020", was adopted that from the 2017 to 2025 the GDP PPP $\mathrm{PC}$ in Serbia will grow at an average rate of 5.5\% [13-14].

\section{$P_{1}-$ The factor of specific fuel consumption}

The pace of improvement of energy efficiency of motor vehicles by the end of the twentieth century was quite slow. The automobile market is dominated by the sales trend of bigger, stronger and more comfortable vehicles (such as, more often the presence of vehicles air conditioners, etc.) that use more energy per distance travelled, thus reducing the effects of savings on the basis of continuous technological and technical progress in the field of production of energy efficient engine.

From 2000 to 2005, significant progress was done in terms of increasing the energy efficiency of the vehicle engine. Specific consumption of motor fuel, measured in $L$ per $100 \mathrm{~km}$, has decreased from 2000 to 2005 from about 11.0 to 10.3 [15-17].This corresponds to average increase energy efficiency by about $1.4 \%$ per year. Increased efficiency is the result of combining the effects of increasing fuel prices, motivation for restrained behaviour in driving and designing more fuel-efficient engines.

The increasing number of vehicles with higher coefficients of specific energy consumption in recent years, such as SUV (sport utility vehicle), failed to threaten the downward trend in specific energy consumption in transportation sector (Figure 2). In support of continued downward trend and environmental directives of the EU from 2009 in the specific $\mathrm{CO}_{2}$ emissions for new vehicles[18], projections of different institutions show further reduction in specific energy consumption at a rate of about $1.25 \%$ per year, which by 2030 could lead to an average consumption of motor fuels from $7.5 \mathrm{~L} / 100 \mathrm{~km}$ [15]. In the analysis of specific fuel consumption in Serbia, the actual trend for the European Union (EU) was adopted, where statistics of the candidate countries for EU membership were taken in the analysis.

\section{$P_{2}$ - The average mileage factor}

In the last two decades, there has been a trend throughout Europe that the average mileage per vehicle per year decline at an average rate of $0.1 \%$ per year (Figure 3). Predictions are that this trend will hold in the future [17]. This trend is adopted in this analysis for Serbia.

\section{$P_{3}-$ Factor changes in crude oil prices (Figure 4)}

Numerous studies around the world contain a prediction of price movements of crude oil in the future. One of most relevant organization that deals with this issue is the U.S. Energy Information Administration (U.S. EIA). In its annual energy outlook for 2010, it provides a forecast of crude oil prices until 2035, in several different scenarios. In this analysis, the so-called "'middle" scenario has been adopted [19-20].

In the study "European Energy and Transport: Trends to 2030 - Update 2007" it was concluded that with doubling the price of crude oil, motor fuel price increases on average by $35 \%$, which then leads to a 


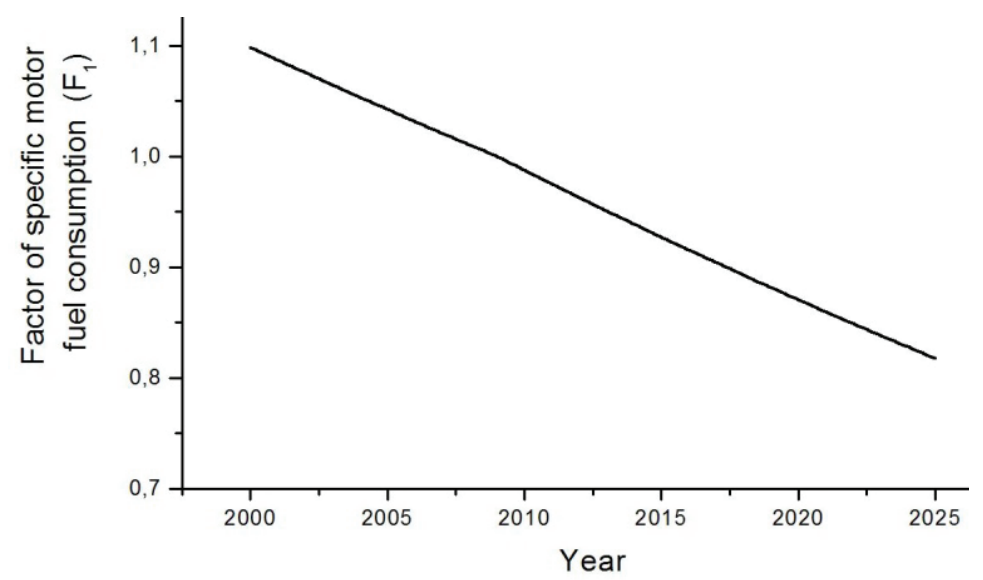

Figure 2. Development of factor of specific motor fuel consumption in Serbia (2000-2025).

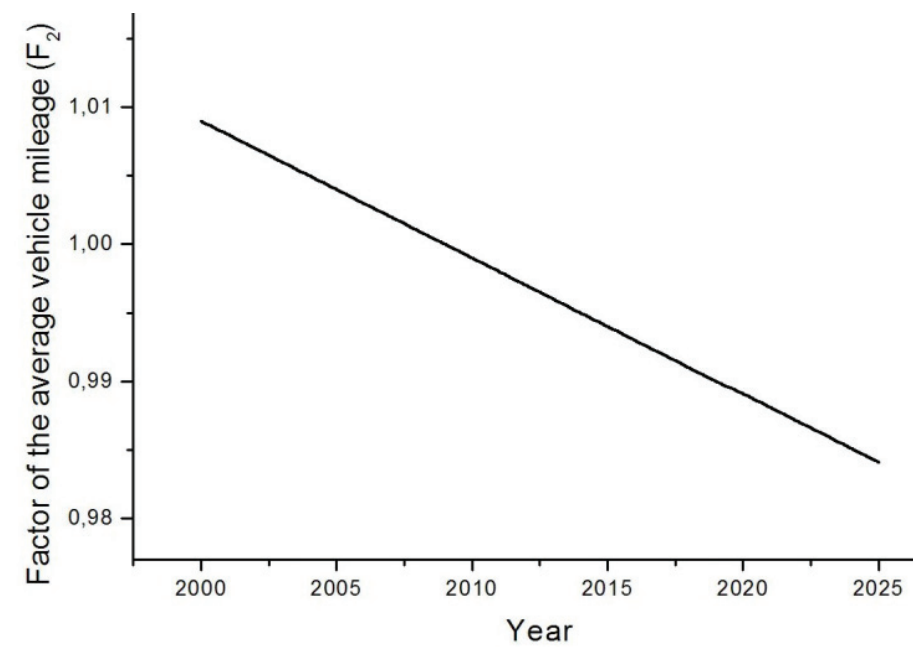

Figure 3. Development of factor of the average vehicle mileage in Serbia (2001-2025).

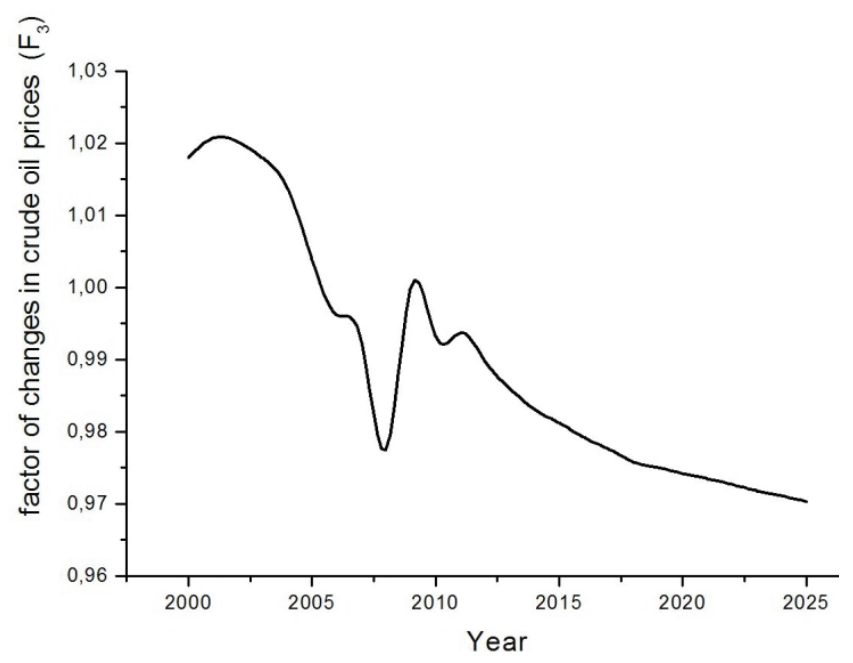

Figure 4. Development of factor changes in crude oil prices (2001-2025).

decrease in sales of motor fuels by about 3.5\% [17]. A similar conclusion was reached by Goodwin [6].

$\mathrm{P}_{4}$ - Impact Factor of alternative fuels (Figure 5)

Traditional fuels are products obtained by processing crude oil. Fossil fuels have several key short- comings, such as limited reserves of crude oil and the fact that the process of fossilization takes millions of years. There are also problems related to environmental protection, because fossil fuels release large amounts of greenhouse gases. Therefore, it is important to serious consideration of substitution of traditional mo- 


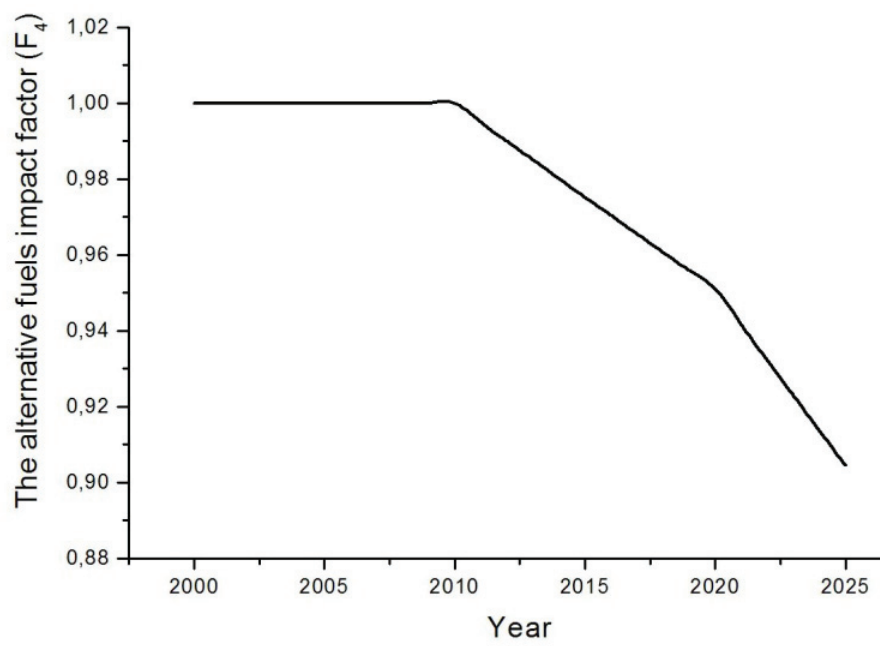

Figure 5. Development of the alternative fuels impact factor in Serbia (2001-2025).

tor fuels with alternative fuels, in order to protect the environment and relieve pressures arising as a result of reduction in crude oil stocks. The most commonly used alternative fuels are biodiesel, electricity, ethanol, hydrogen, methanol, natural gas, propane, etc.

In March 2006, the Council of Europe called on the leaders of European countries to meet the steps of using renewable energy sources in a plan such that by 2015 , energy from renewable sources would make up $15 \%$ of total energy consumption, and by $2020,25 \%$ [21]. As for the transport sector, the ratio of renewable fuels in the total quantity of produced fuel should reach $5 \%$ by 2015 and $10 \%$ by 2020 [22-24].

As Serbia moves closer to EU membership, it will have to comply with all the decisions taken by EU institutions. However, Serbia has not yet been able to fully implement all the recommendations and directives regarding the dynamics of replacing fossil fuels with renewable fuels. Therefore, it is unrealistic to expect that the successful implementation of already mentioned dynamics of the replacement of fossil fuels in Serbia would be realized. All new EU members have received benefits in terms of these deadlines. Time limits and extent of substitution of traditional fossil fuels with renewable fuels in this paper for Serbia moved to $5 \%$ by 2020 and $10 \%$ by 2025 .

\section{$P_{5}-$ The impact factor of vehicles air conditioning (Figure 8)}

Passenger car manufacturers provide data indicating that the use of air conditioning while driving increases fuel consumption by an average of about $6 \%$ [25]. The assessment adopted in this analysis is that the air conditioner in the vehicle is used an average of 60 days a year. This would mean, looking at individual vehicles, that the effect of using air conditioning on fuel consumption is positive and that is about $1 \%$ per annum.
In order to estimate how much the use of air conditioners in vehicles affect fuel consumption it was necessary to introduce additional information year by year: the total number of registered vehicles in Serbia, $A_{\mathrm{uk}, j}$, and the number of vehicles equipped with air conditioning, $A_{k, j}$ :

$F_{5, j}=1+0.01 A_{k, j} / A_{u k, j}$

The total number of registered vehicles in Serbia was obtained based on the equation:

$A_{\mathrm{uk}, j}=S T_{j} \times$ Motorization $_{j} / 1000$

where $S T_{j}$ represents population number per year $j$; Motorization $_{j}$ is number of vehicles per 1000 inhabitants in a chosen year $j$.

It was noted that the correlation of development of motorization and GDP per capita follows a sigmoid or "S curve" [26]. In the case of Serbia, the correlation of $G D P P P P_{\mathrm{PC}}$ and motorization when "S curve" is applied would look like as seen in Figure 6.

In order to predict how $A_{\mathrm{uk}, j}$ will change in the future, as motorization had already been calculated, it was necessary to predict population trends. The Statistical Office of Serbia includes the prediction of population trends in Serbia until the 2027 and for some years: 2012, 2017, 2022 and 2027 [27].

To determine the parameter $A_{k, j}$, an assessment was made providing the percentage of vehicles that have air conditioning based on the production year of vehicles, as shown in Table 1 . Then, the number of air-conditioned vehicles in Serbia was determined by the equation:

$\mathrm{A}_{\mathrm{k}, j}=\sum_{l=0}^{6} P K A_{j} \times A_{\mathrm{E}_{l, j}}$

where $P K A_{j}$ represents percentage of air-conditioned vehicles in the year $j ; A_{E_{l, j}}$ is number of vehicles in the 


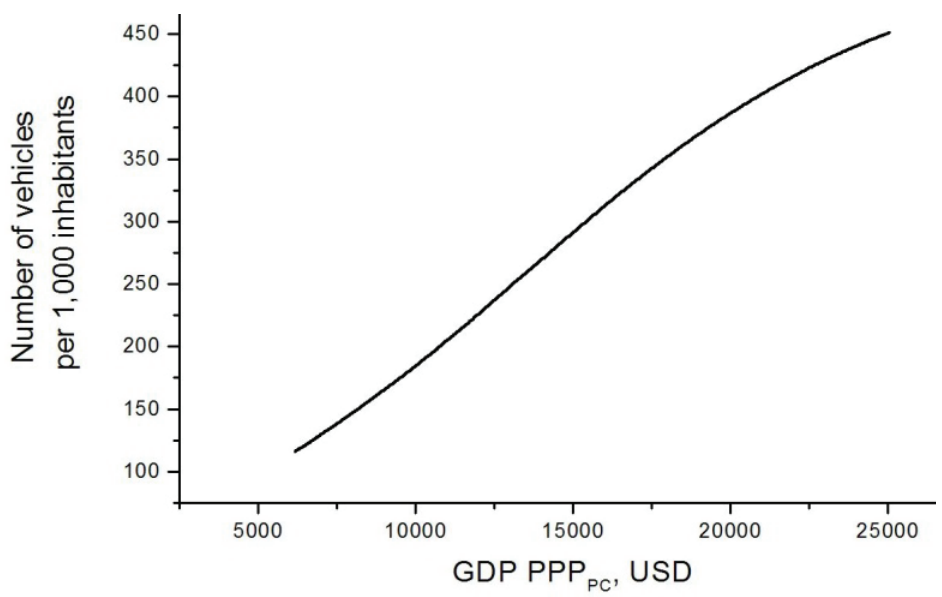

Figure 6. Development of the number of vehicles per 1,000 inhabitants in Serbia (2001-2025).

Table 1. The percentage of vehicles that use air conditioning in Serbia

\begin{tabular}{lcc}
\hline Vehicle production per year & Group of vehicle by age & Number of air-conditioned vehicles, \% \\
\hline$<07.1992$ & $E_{0}$ & 0 \\
$07.1992-01.1996$ & $E_{1}$ & 1 \\
$01.1996-01.2000$ & $E_{2}$ & 10 \\
$01.2000-01.2005$ & $E_{3}$ & 35 \\
$01.2005-09.2009$ & $E_{4}$ & 60 \\
$09.2009-09.2014$ & $E_{5}$ & 80 \\
$>09.2014$ & $E_{6}$ & 95 \\
\hline
\end{tabular}

vehicle group $E_{l}$ in the year $j ; l, 1-6$, is number of vehicle group according to vehicle production year.

As there are no statistics that give age of the vehicle fleet in a given year in Serbia, a search was conducted for analogies with some European countries for which such data are available. The European Statistical Agency (Eurostat) provides such data for most EU countries for the period 1993-2007. Selected as relevant are those countries whose GDP $P P P_{\mathrm{PC}}$ in the mentioned time interval was moved in the interval in which the GDP PPP $P_{\mathrm{PC}}$ will move in Serbia in the period 2010-2025 [13].

Based on the age of vehicles in these countries, the age of the fleet in Serbia year by year in the period 2008-2025 was derived. The only data that were available for the motor pool in Serbia were taken from a study that was done the market research conducted by Company Synovate in Serbia in 2008 [28]. Results from this market research were most similar to achievements in Hungary. Therefore, the adopted assumption is that the age of the fleet in Serbia in the period 2008-2025 will develop as it has developed in Hungary.

Distribution of vehicles by age groups, $E_{0}, E_{1}, \ldots, E_{6}$ (which are given in Table 1), in each individual year during the period 2001-2025 in Serbia, is given in Figure 7 .

\section{RESULTS AND DISCUSSION}

For Serbia, there is no long-term forecast of consumption of motor fuels. Therefore, development of the model presented in this paper is an attempt at "making tools" that could provide an answer to this question. The results include the total consumption of motor fuels, as well as their individual consumption, during the period from 2010 to 2025 . The period from 2001 to 2009, for which statistics are available on consumption of motor fuels, was used as a control period for model validation.

The model (Eq. (1)) gives the result about total consumption, but not on individual motor fuel consumption. Consumption of individual products is obtained based on the assessment of relation between gasoline/diesel demand in the period 2010-2025, and estimates of consumption of LPG, in the same period; the sum of consumption of gasoline, diesel and LPG fuel gives the total consumption.

The ratio of consumption of gasoline and diesel fuel in Europe has been intensively monitored for last few decades [16], and it was noticed that most countries in Europe have a similar trend $[17,19,20]$. The last decades of the twentieth century ratio of consumption of gasoline and diesel fuel went from 2.5 to 0.4 in recent years [16], while the correlation had a decreasing S-shape $[29,30]$. In order to predict how the relation- 


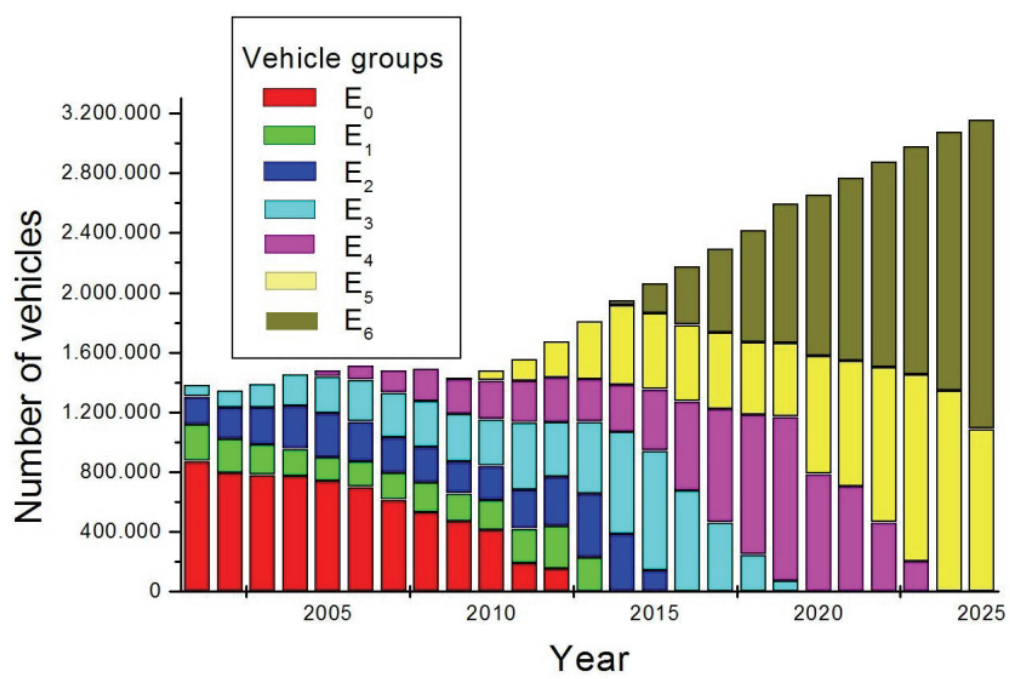

Figure 7. Prediction of the number of vehicles in Serbia by age group, $E_{0}-E_{6}$, from the Table 1 (2001-2025).

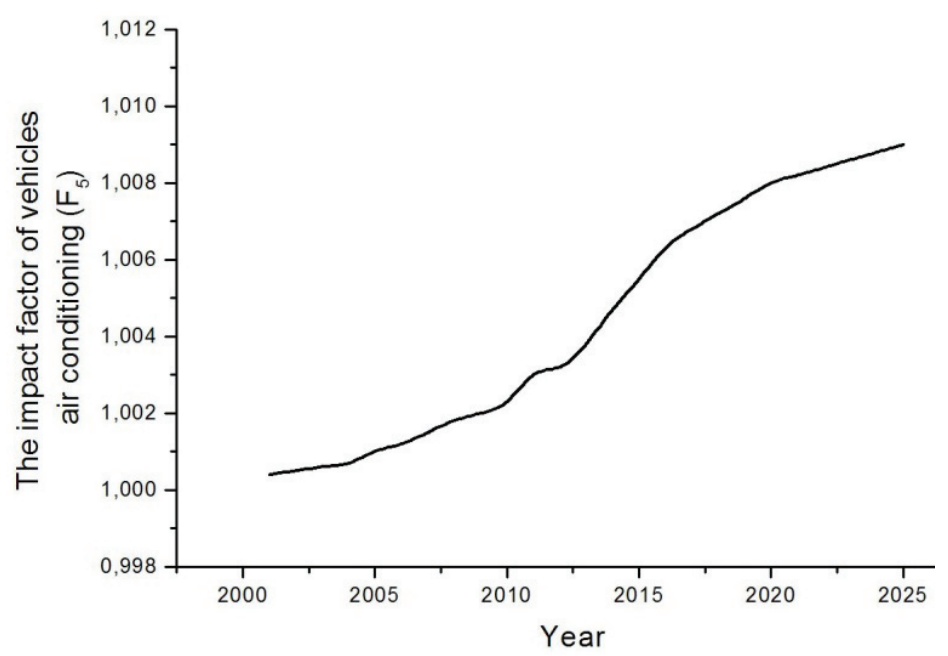

Figure 8. Development of the impact factor of vehicles air conditioning in Serbia (2001-2025).

ship of consumption gasoline/diesel fuel will develop in the following period, the data from the Statistical Office of Serbia and the data on that relation in some comparative countries (Croatia and the New EU Member States - Bulgaria, Hungary, Czech Republic, Estonia, Lithuania, Slovenia, Slovakia, Cyprus, Poland and Malta) were analyzed. Based on the analysis of consumption of gasoline and diesel fuel in all these countries and realized values in Serbia in the period 2001-2009, the dependence for Serbia from 2010 to 2025 was obtained, Eq. (5), which is shown in Figure 9:

$$
C_{g / d}=\frac{0.494}{1+e^{\left(Y_{r}-2004.6\right) / 1560}}+0.337
$$

$\chi^{2}$ distribution value is $3.842 \times 10^{-4} ; C_{g / d}$ represents the ratio of consumption gasoline/diesel fuel; $Y_{r}$ is year.

In order to predict consumption of LPG in Serbia, the analogy with the data of some comparative countries was also used. The general trend in Western Eu- rope is the stagnation of consumption of LPG and it is anticipated that this trend will continue in the future [17]. On the other hand, neighbouring countries, as well as Serbia, which belong to the group of middle income countries, have not yet even entered the stage of saturation in demand. Looking at the historical trend of LPG consumption in the high income countries of Western Europe may be the role model how to predict the development of consumption in the countries of South-eastern Europe. In almost all cases the trend of consumption has a tendency of rapid growth in the first period, then enters a phase of saturation of consumption and ultimately shortly after leads to slight stagnation of consumption [10,31]. For example, McKay in his work modelled dependence of natural gas and GDP per capita by logistic curve [32]. Such a model of consumption of LPG was adopted in the case of Serbia. 


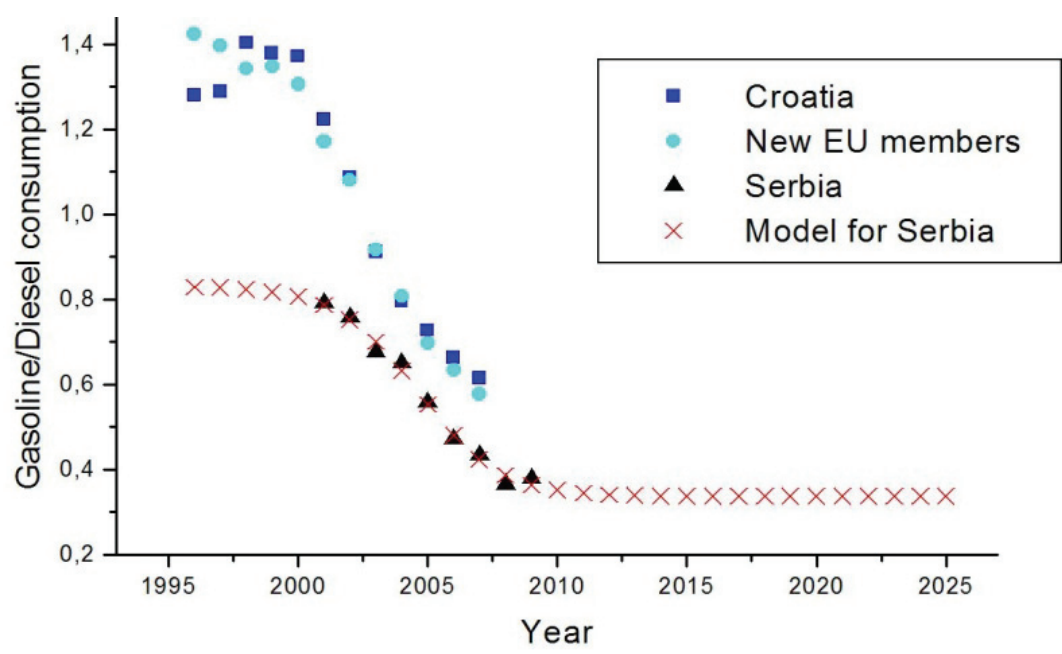

Figure 9. Ratio of realized consumption gasoline/diesel in Croatia, New EU members, Serbia and model results for Serbia.

Through the achieved results of the consumption of LPG in the period 2001-2009 fitted a Boltzmann sigmoid curve, which has the form:

$$
L P G_{j}=\frac{-434974}{1+e^{\left(G D P P P P_{C}, j-8748.96\right) / 1151.23}}+435000
$$

$\chi^{2}$ distribution value is $2.926 \times 10^{8} ; \mathrm{LPG}_{j}$ represents $\mathrm{LPG}$ consumption in the year $j$.

In Figures 10-13 the results of the total consumption of motor fuels and results in derivatives individually are shown. In addition to the results obtained from the model, the results of achieved consumption for the period 2001-2009 are shown in the charts. It may be noted that the model results agree with achieved statistics data very well.

Statistical analysis shows that the correlation coefficient of realized total consumption and modelled consumption in the period 2001-2009 amounts to
0.938, which represents a strongly positive correlation. The accuracy of the model in the control period made it clear that the extrapolation model for a longer period, i.e. forecasting achievement of national consumption of motor fuels by 2025 , makes sense.

Figure 11 shows the model results of gasoline consumption in Serbia in the period 2001-2025. The correlation coefficient between realized and modeled consumption of motor gasoline in the period 2001-2009 is 0.95 . Figure 12 shows the model results of consumption of diesel fuel in Serbia in the period 2001-2025. The correlation coefficient between achieved consumption of diesel fuel and modelled diesel fuel consumption in the period 2001-2009 was also 0.95. Figure 13 shows the model results of consumption of LPG in Serbia in the period from 2001 to 2025 . The correlation coefficient of realized consumption and modelled consumption of LPG for the period 2001-2009 is 0.99 .

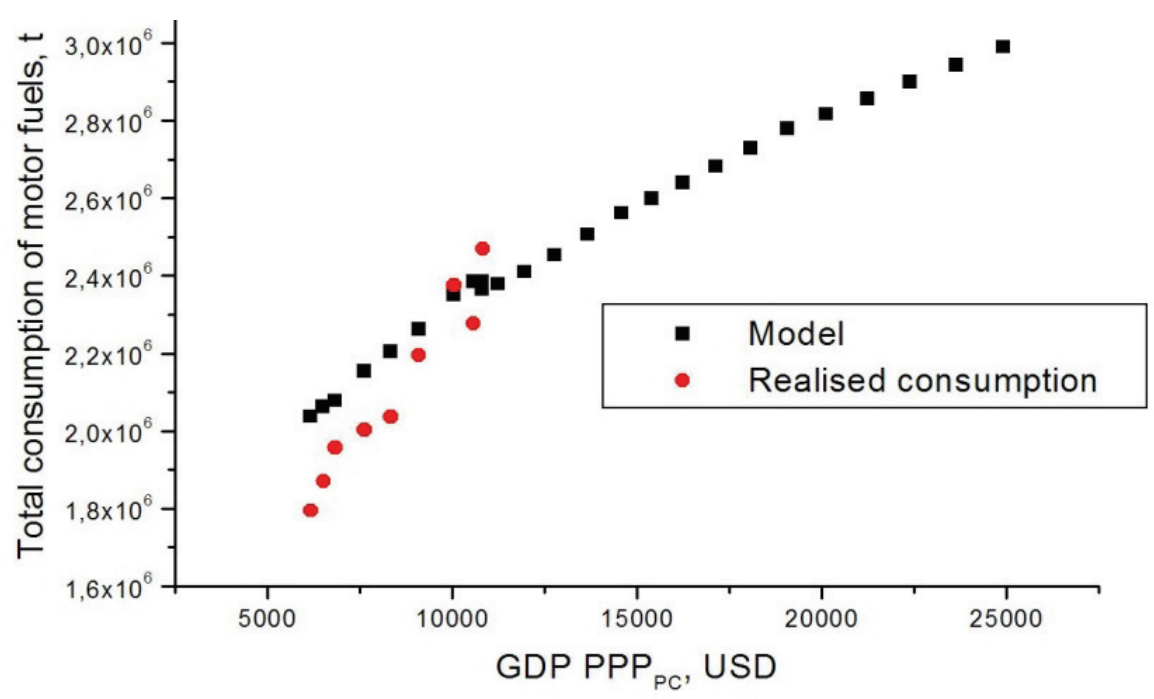

Figure 10. Results of the model of total consumption of motor fuels in Serbia in the period from 2001 to 2025. 


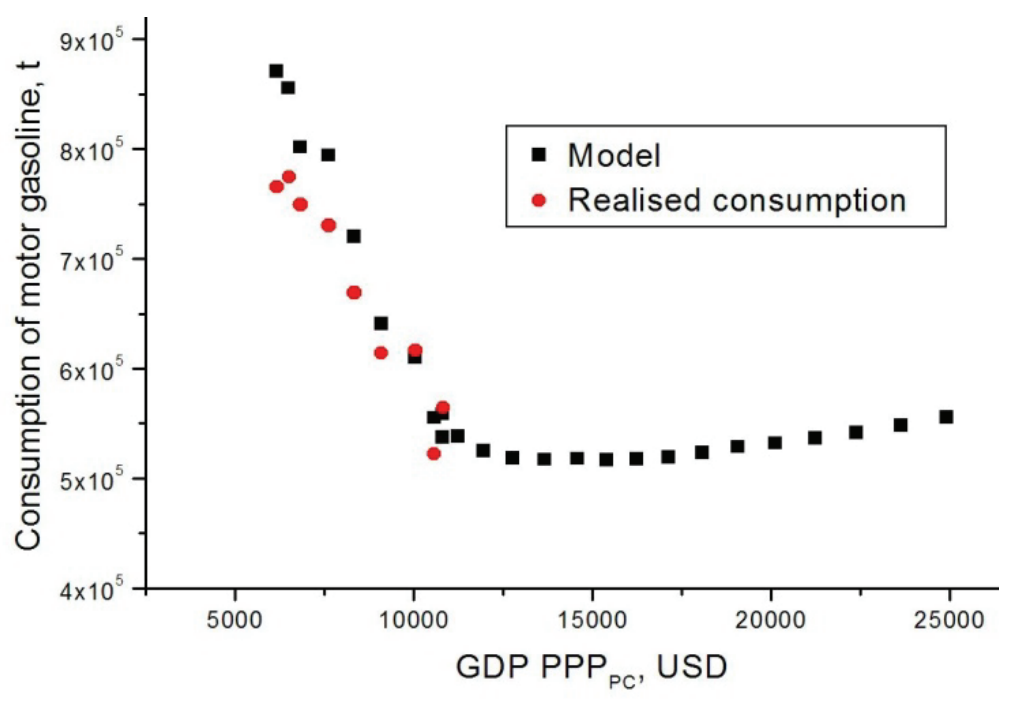

Figure 11. Results of the model of consumption of gasoline in Serbia in the period from 2001 to 2025.

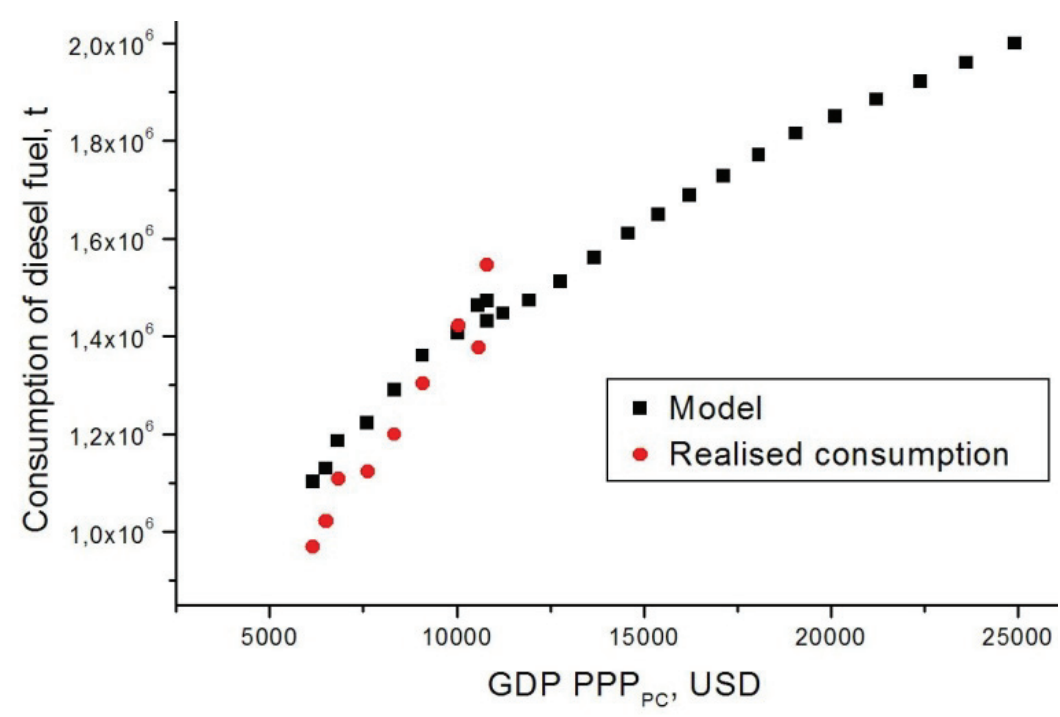

Figure 12. Results of the model of consumption of diesel in Serbia in the period from 2001 to 2025.

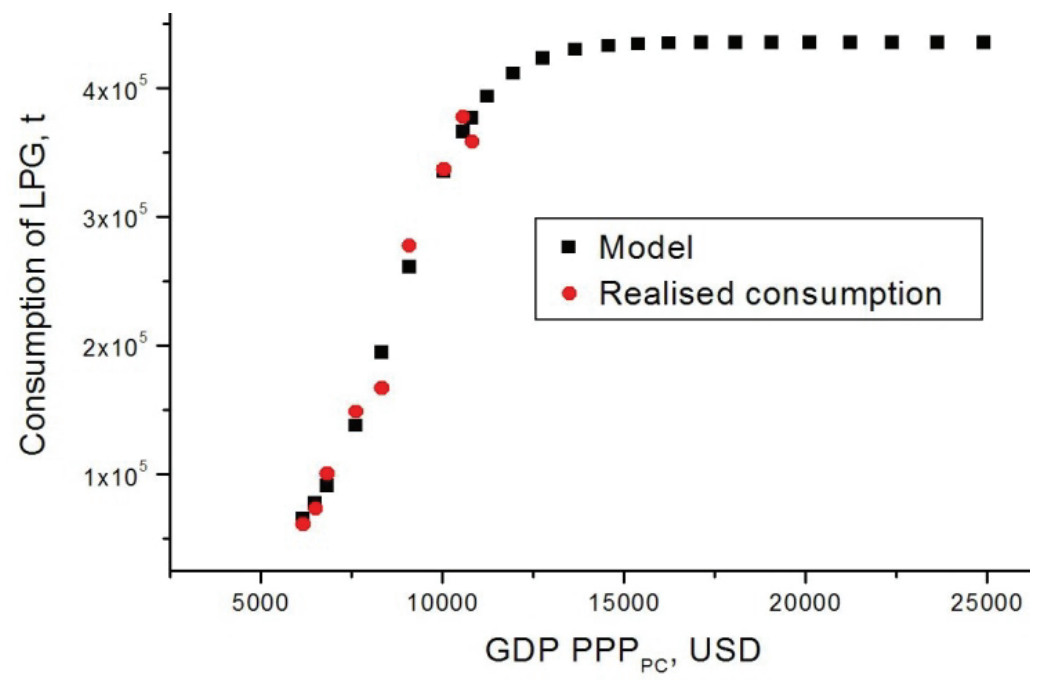

Figure 13. Results of the model of consumption of liquefied petroleum gasses (LPG) in Serbia in the period from 2001 to 2025. 


\section{CONCLUSION}

The development of model for the prediction of consumption of motor fuels was based on the conclusion of many authors that between the energy consumption and economic growth exists a linear correlation, which primarily refers to low and middle income countries, such as Serbia. However, although the linear correlation showed good agreement between $G D P P P P_{\mathrm{PC}}$ and fuel consumption (in the control period from 2001 to 2009), the correction is carried out in order to get more reliable information about future consumption. The literature states that middle income countries follow a linear correlation, and as the amount of income increases, it results in slight saturation of energy. It is believed that, in the future, Serbia's GDP will record considerable growth. Such growth would make Serbia introduced, just before the end of the observation period (2010-2025), in the group of countries with high income, according to the current classification of the World Bank. This means that the model based on a modified linear interdependence would still be applicable. Taking into account all the above, a model was developed, which predicts results for overall consumption of motor fuels in Serbia, as well as gasoline, diesel and LPG fuel individually, in the time interval from 2010 to 2025.

The model results indicate that the total consumption of motor fuels in the period until 2025 in Serbia will grow, but with a saturation tendency. The total consumption in Serbia in 2025 will be $47 \%$ higher than in 2001, and 26.5\% higher than in 2010; and it will go from 2.36 Mt in 2010 to $2.99 \mathrm{Mt}$ in 2025. Consumption of diesel fuel will have a similar development trend like the total consumption, but with fewer saturation tendencies. This fuel has greater increases in consumption in relation to all derivates overall, from 2001 to 2025 consumption will increase for about $82 \%$. Looking at the period from 2010 to 2025 this increase will be $40 \%$; from 1.43 to $2 \mathrm{Mt}$, respectively. Consumption of motor gasoline will record a declining trend or stagnation until the period 2015-2016, when it should start to grow again moderately. This stagnation will result in a drop of consumption in the period 2001-2016 as much as $42 \%$. The period after 2015-2016 follows recovery and increase consumption of about $7.5 \%$. Looking at the whole period 2001-2025 there will be a decline in consumption of about $46 \%$. In the year of minimum consumption (2016) it will amount to $516.5 \mathrm{Kt}$, while by 2025 it will rise to $555 \mathrm{Kt}$. Finally, consumption of LPG in Serbia will keep the trend of dynamic growth until 2012, during the period from 2012 to 2015-2016 should come to a slowdown in demand, so by 2017 consumption will fully enter into the saturation phase. During a very intense consumption period (2001-2010), the increase was greater than $550 \%$ and would be followed by saturation until 2025. Total increase in LPG consumption in the whole period will be at about $670 \%$. From 2010 to 2025 consumption will move from 376 to $435 \mathrm{Kt}$, respectively.

\section{Acknowledgment}

These results are part of the project No. 45001, supported by the Ministry of Education and Science of the Republic of Serbia. Useful suggestions and comments from a referee of this journal are greatly appreciated.

\section{REFERENCES}

[1] M. Belhaj, Vehicle and fuel demand in Marocco, Energ. Policy 30 (2002) 1163-1171.

[2] R. Hannesson, Energy and GDP growth, Int. J. Energ. Sect. Manage. 3 (2009) 157-170.

[3] S. Ghosh, Future demand of petroleum product in India, Energ. Policy 34 (2006) 2032-2037.

[4] B.N. Huang, M.J. Hwang, C.W. Yang,Causal relationship between energy consumption and GDP growth revisited: A dynamic panel data approach, Ecol. Econ. 67 (2008) 41-54.

[5] S. Pokharel, An econometric analysis of energy consumption in Nepal, Energ. Policy 35 (2007) 350-361.

[6] P. Goodwin, J. Dargey, M. Hanly,Elasticities of Road Traffic and Fuel Consumption with Respect to Price and Income: A Review, Transport Rev. 23 (2003) 275-292.

[7] J. Bentzen, Elasticities in oil demand in developing countries, Pac. Asian J. Energ. 9 (1999)21-30.

[8] F. Lescaroux, O. Reich, The impact of automobile diffusion on the income elasticity of motor fuel demand, Energy J. 29 (2008) 41-60.

[9] The Word Bank, How we Classify Countries, 2011, http://data.worldbank.org/about/country-classifications.

[10] World Energy Outlook 2009, IEA, Paris, 2009.

[11] Uredba o izmenama i dopunama Uredbe o utvrđivanju Programa ostvarivanja Strategije razvoja energetike Republike Srbije do 2015. godine za period od 2007. do 2012. godine, Vlada R. Srbije, Sl.glasnik RS 27/10, Beograd, 2010, str. 64-96.

[12] The Word Bank, GNI per capita, PPP (current international \$), 2011, http://data.worldbank.org/Indicator/NY.GNP.PCAP.PP.CD.

[13] [International Monetary Fund, IMF Data Mapper, 2011, http://www.imf.org/external/datamapper/index.php.

[14] Postkrizni model ekonomskog rasta i razvoja Srbije 2011 to 2020, FREN \& MAT, Ekonomski institut, Ekonomski fakultet, Beograd, Avgust 2010.

[15] P. Fehrentz, Trend towards buying fuel - saving cars reduces fuel consumption, Statistiches Bundesamt Deutschland, 2011, http://www.destatis.de.

[16] European Commission, 2011, http://epp.eurostat.ec.europa.eu.

[17] European Energy and Transport. Trends to 2030 - Update 2007, EC, DGTREN, Luxembourg, 2008.

[18] Regulation (EC) No 443/2009, EC, Brussels, 2009. 
[19] International Energy Outlook 2009, U.S. EIA, Washington DC, 2009.

[20] Annual Energy Outlook 2010 - With Projection to 2035, U.S. EIA, Washington DC, 2010.

[21] Presedency Conclusion 7775/1/06 REV 10, Council of the EU, Brussels, 2006.

[22] Directive 2009/28/EC, EC, Brussels, 2009.

[23] Directive 2003/30/EC, EC, Brussels, 2003.

[24] Directive 2001/80/EC EC, Brussels, 2001.

[25] S. Roujol, R. Joumard, Influence of passenger car auxiliaries on pollutant emission factors within the Artemis model, Atmos. Environ. 43 (2009) 1008-1014.

[26] G. Radnays, Paving the Way to Green Solutions, Toyota Motor Europe, 2008.
[27] Republika Srbija, Republicki zavod za statistiku, 2010, http://webrzs.stat.gov.rs.

[28] S. Prvulović, D. Velimirović, D. Manasić, I. Minić, Istraživanje tržižta automobile Srbije2008, Synovate Serbia, Beograd, 2008.

[29] M. Pock, Gasoline and diesel demand in Europe: new insights, Economics Series 202, Institute for Advanced Studies, Vienna, 2007.

[30] An economic and security of supply analysis of the widening EU diesel deficit, Factsheet, EBB, Brussels, 2008.

[31] EU Energy and Transport in Figures - Statistical Pocketbook 2009, EC, DG TREN, Luxembourg, 2009.

[32] R.M. Mackay, S.D. Probert, Modified Logit-Function Demand Model for Predicting National Crude-Oil and $\mathrm{Na}-$ tural-Gas Consumptions, Appl. Energ. 49 (1994) 75-90.

\section{IZVOD}

MODELOVANJE POTROŠNJE MOTORNIH GORIVA U SRBIJI SA PROJEKCIJAMA DO 2025. GODINE

Dalibor Marinković ${ }^{1}$, Zoran Popović ${ }^{1}$, Aleksandar Orlović ${ }^{2}$, Mirjana Ristić ${ }^{2}$

${ }^{1}$ Univerzitet u Beogradu, Institut za hemiju, tehnologiju i metalurgiju, Beograd, Srbija

${ }^{2}$ Univerzitet u Beogradu, Tehnološko-metalurški fakultet, Beograd, Srbija

(Naučni rad)

Ovaj rad se bazira na primeni metoda matematičke statističke analize koji mogu da posluže za predviđanje razvoja potrošnje motornih goriva u Republici Srbiji. Model je baziran na linearnoj zavisnosti rasta obima potrošnje motornih goriva od razvoja bruto domaćeg proizvoda po glavi stanovnika koja je potom korigovana uvođenjem pet dodatnih uticajnih parametara. Svakom od ovih parametara dodeljen je odgovarajući koeficijent koji odmerava specifični uticaj istog na potrošnju motornih goriva. Rezultati modela ukazuju da će ukupna potrošnja motornih goriva u Srbiji od 2010. do 2025. biti uvećana za 26,5\%, sa 2,36 Mt/god na 2,99 Mt/god. Potrošnju dizel goriva očekuje nastavak intenzivnog rasta, doduše nešto usporen u odnosu na ostvarenja u prethodnoj dekadi i do 2025. potrošnja će dostići nivo od blizu 2 Mt. Postojeći trend opadanja tražnje motornih benzina biće zaustavljen 2015-2016, nakon toga sledi spori rast tražnje i do 2025. potrošnja će biti oko 550 Kt. Potrošnja tečnog naftnog gasa (TNG) nakon intenzivnog rasta od 2015. ući će u fazu saturacije, tako da će u periodu 2010-2025. godine zabeležiti mali porast potrošnje - sa 377 na $435 \mathrm{Kt} /$ god.

Ključne reči: Potrošnja naftnih derivata • BDP • matematički model • Srbija 